\title{
Physics of the Solid State
}

\author{
Fiftieth Anniversary of the Physical Society of Zurich
}

$\mathrm{T}$ HE Physical Society of Zurich celebrated its fiftieth anniversary by holding a meeting on January 13-16 to discuss the "Solid State".

This Society was originally founded by students in order to discuss physical and technical problems. One of the early and rather unusual rules governing the selection of new members was that no professors should be admitted. This rule was abandoned later when the Society included in its list of members such distinguished names as: P. Weiss, A. Einstein, M. von Laue, P. Debye and E. Schrödinger, who were all at some time on the staff of either the University or the Technical High School in Zurich.

The jubilee meeting was opened by the president of the Swiss Board of Education, and his address was followed by a speech from Prof. P. Weiss, of the University of Strasburg, who represented the foreign members of the Society.

The first scientific address was given by Prof. P. Niggli, of the Technical High School, on the subject of "Mineralogical Problems of Crystal Structure". Prof. Niggli gave first a general survey of the various crystal types and discussed in particular the case in which whole groups of the constituent parts of the crystal are partially substituted by other groups without thereby altering the lattice. He gave the rules governing these substitutions, and discussed the problem on the basis of the geometrical structure theory.

On the following day, Prof. W. L. Bragg, of the University of Manchester, gave an account of the structure of binary alloys in connexion with the Hume-Rothery rule, and discussed the lattice transformation in alloys in their relation to order-disorder phenomena.

Prof. P. Debye, of the Kaiser Wilhelm Institute of Physics, Berlin, dealt in his lecture with the semicrystalline nature of liquids. He discussed the effect of the waves of thermal agitation in a liquid upon the scattering of monochromatic light by the liquid. Whereas, in a gas, light originally monochromatic becomes slightly less so after it is scattered, in an ideal crystal, this light splits into two components; and in a liquid, generally speaking, into three spectral lines, except when the coefficient of expansion becomes zero, as for example in water of maximum density, where only two lines appear, as predicted by the theory. From these experiments, Prof. Debye concludes that a liquid is, on the whole, much nearer to a solid than it is to a gas.

On the following day, Dr. A. Müller, of the Royal Institution, London, gave a summary of the work on long-chain compounds of the paraffin type. $\mathrm{He}$ discussed the relations between the structure and physical properties of these substances and deait with the problem of crystal transformations.

Prof. H. Mark, of the University of Vienna, lectured on the kinetics of polymerization of certain substances which form very long chains, and gave an account of the elasticity of rubber, which he treated as a problem of statistics of the configuration of these long chains.

The evening lecture was delivered by Prof. A. Sommerfeld, of the University of Munich, who gave an excellent account of the modern theory of the metallic state, and of the specific heat and electrical conductivity of metals.

The final address was by Prof. M. von Laue, of the Cniversity of Berlin, who discussed the theory of the "Kossel- and Kikuchi-lines" which are observed when a source of X-rays or electron waves is placed inside a crystalline medium.

The papers presented at the meeting will be published together.

The meeting was woll organized and attended, for which the president of the Society, Dr. R. Sänger, was largely responsible. At the same time, there was an informal atmosphere and lively discussion. The meetings arranged by the Physical Society in Zurich nearly every year are now well-known in scientific circles, and provide opportunities for the exposition of recent scientific work in a place convenient for scientific men of all nations. A. M.

\section{International Cancer Research}

$\mathrm{R}^{\mathrm{n}}$ EFERENCE has already been made in these columns to the Second International Congress of the Scientific and Social Campaign against Cancer which was held in Brussels last autumn (NATURE (1936), 138, 727). The text of fifty-five reports or reviews which were read at the Congress have now been published*. Each report is given at length in one of the six official languages, while summaries of the reports are given in all six languages. Some of the reports, such as that of Cook, Haslewood, Hewett,

* Ind International Congress of the Scientific and Social Campaign against Cancer. Yol. 1, Keports. Pp. xvi +503. (Bruxelles: Ligue Nationale Belge contre le Cancer, 1936.)
Hieger, Kennaway and Mayneord on "Chemical Compounds as Carcinogenic Agents" and that of Reding on "Predisposition and Resistance to Cancer", have good bibliographies, while others have no references. The greater part of the volume is concerned with the biology, diagnosis and therapy of cancer, and there are interesting reviews on the statistical investigation of mortality from eancer in different States and among different races.

The last four papers on the statistics of morbidity and mortality from cancer are from London, Munich, New York and Batavia, and show that the total mortality from cancer is of the same order in almost 
all parts of the world. As Dr. Cramer points out, "cancer in man is an experiment carried out on man of which the end results are represented by the cancer mortality statistics, while the beginning of the experiment is unknown". The problem of the cause of cancer is to determine the beginning of the experiment, and hints of this are given by analysis of the statistics. Dr. Bonne gives relative cancer mortality figures for Malays and Chinese in Batavia, Chinese in Singapore, Filipinos in Manila, Japanese in Tokyo and Austrians in Innsbrück. The total mortality from cancer in these groups is of the same order, but the distribution according to sites is quite different. Cancer of the liver, which is rare in Europe, is common in the East, and cancer of the lung is more common in Europe than in the East. The results given in these statistical papers show the magnitude and extent of the fight against cancer.
The fact that these reviews are given by invitation by scientific workers of sixteen different countries indicates how widespread is the effort to combat malignant disease. The report brings together work from research workers in chemistry, histology, medicine, surgery, radiology, geography, and statistics, and will no doubt have a beneficial influence in making workers aware of what is being done in cancer research outside their own fields. It is probably as good a general review of the whole field as can be found, although there are too few illustrations in some parts of the work, and several chemical formulæ are incorrectly represented.

The reports deal mainly with work of the last three years, and if similar publications are produced at each triennial congress, they would continue to improve co-operation between research workers in different countries and sciences.

\section{Historic Flora of Mexico}

$\mathrm{T}$ HE Smithsonian Institution has just received, for study and identification of specimens, part of the celebrated Sesse and Mocino collection of the flora of Mexico, which recently came to light in Madrid after more than a century. The collection was sent by Spanish officials just before the outbreak of the revolution to Dr. Paul Standley, of the Field Museum of Natural History in Chicago, an authority on the plants of Mexico. Dr. Standley has distributed it to American institutions specializing in various plant families represented, for study under his direction.

The story of this collection is one of the most colourful in the history of botanical exploration. In 1787, Charles III of Spain sent to Mexico a botanical expedition headed by Dr. Martin Sesse y Lacasta, the most eminent of Spanish botanists, for the purpose of making a complete collection of the flora of Mexico and setting up a chair of botany in the National University at Mexico City. The lectures of Sesse and his companions aroused the interest of a young Mexican physician, Dr. José Mariano Mocino. He became so absorbed in botany that he gave up his practice, obtained an appointment as a member of the expedition, and for more than twenty years engaged in almost constant exploration. He covered all central Mexico, and made trips so far south as Guatemala and so far north as California. In 1804, Sesse and Mocino went to Spain, where they began to work up their collections. Sesse died five years later, and Mocino was made director of the Cabinet of Natural History in Madrid. About this time, Madrid was invaded by the French. A change in Government meant nothing to the Mexican botanist, absorbed in the plants for which he had risked his life so often. He was popular with the invaders, and they did not disturb him. Then the French were driven out and the vengeance of the Spaniards, incensed at his "traffic with the enemy", fell upon the head of Mocino. He was thrown into prison and placed in chains, to be rescued by the return of the French army.

Once again the French were driven out. This time Mocino took no chances. He loaded his manuscripts and drawings into a mule cart and, old and feeble as he was, walked beside it throughout the hasty retreat across the mountains. He finally arrived safely at Montpellier in France, but nearly blind and penniless. He might have starved had it not been for the friend. ship of the celebrated Swiss botanist De Candolle. The latter, however, borrowed his drawings and took them with him to Geneva. Mocino in the meantime was negotiating to return to Spain, and finally was assured that he would not be bothered. $\mathrm{He}$ wrote to De Candolle asking for the immediate return of his drawings. The result was one of the most extraordinary incidents in the history of botany. De Candolle asked for volunteers-anybody in Geneva with any artistic talent - to copy them as a patriotic duty. The volunteers came-society girls, college students, ministers. Altogether 120 of them were put to work and completed the job in ten days. With his drawings returned, Mocino started back to Spain. In Barcelona he was taken ill and died, giving his drawings to a physician who had be. friended him. This man apparently attached no value to them and they disappeared. Had it not been for De Candolle's copies, they would have been lost completely to science.

Meanwhile, the manuscripts of Sesse and Mocino and the plants they had collected remained at Madrid. Nobody attached any value to them or paid any attention to them. It was not until 1888, nearly a century after the collections were made, that the manuscript was published in Mexico City. Mean. while most of the plants had been rediscovered and described, so that Mocino and Sesse were deprived of their hard-earned glory.

The specimens, however, remained at Madrid. Many of the species described in the manuscript could not be identified with any known in Mexico at the time of the publication, and it was impossible to match the descriptions and other specimens. Perhaps there are species still unknown to science. It is noteworthy that Mocino was especially interested in medicinal plants, and spared no effort to obtain everything to which curative properties were ascribed by natives. 